\title{
A Comprehensive Literature Review of Green Supply Chain Management
}

\author{
Abhijna Neramballi, Movin Sequeira, Martin Rydell, Alexander Vestin, Maria Ibarra \\ School of Engineering, Jönköping University \\ P.O. Box 1026, SE 55111 Jönköping, Sweden \\ neab15AN@student.ju.se; semo1575@student.ju.se
}

\begin{abstract}
In a competitive market, organizations expand their supply chain on a global scale. Pressure from customers, stakeholders, legislation and environmental organizations have pushed companies to be more considerate of the environmental impacts of their supply chain. This development has put focus on sustainability within supply chains, leading to the rise of Green Supply Chain Management (GSCM). The purpose of this research is to create a conceptual model to present the vastly varied literature within the area of GSCM in a structured way, in order to promote environmental and in turn, overall supply chain performance. The research methodology includes a literature review using 125 peer-reviewed journal articles from 2013 to 2016 published in 19 journals. Out of the 125,10 journal articles were selected based on their focus in regard to the subject. The articles were chosen to attain a vantage point in view of critical factors within environmentally sustainable supply chains with a focus on optimizing performance. This paper contributes to theory by presenting a conceptual model for optimizing performance in green supply chains. Drivers, which promote Green Supply Chain (GSC) are classified as re-active and pro-active, and the main methods used for optimizing performance are concluded to be collaboration, metrics to monitor performance and practices such as green purchasing, ecodesign, reverse logistics and legislation. The review may be of use to both academics and companies as it outlines proven ways to implement green supply chain with high performance.
\end{abstract}

Keywords: green supply chain management, sustainable supply chain, supply chain, performance optimization

\section{Introduction}

In order to be more competitive in the highly globalized market organizations tend to expand their supply chain network throughout the world. This has enormously increased humanity's demand for natural resources and in order to realize sustainable development, it has to be balanced with the planet Earth's supply of such resources [1]. The date 20 ${ }^{\text {th }}$ October, 2013 marked the Earth Overshoot Day on which the Earth's annual resource budget was exhausted [2]. This indicates that in order to meet the ever increasing demand, resources of 1.5 Earths is required and at this rate, resources of two planets will be needed by 2030 . The outdated paradigm that the natural resources are infinite and that the regenerative capacity of the environment can compensate for all human action is no longer acceptable making sustainability a crucial issue for the present and future generations [3]. Brundtland Commission defines sustainability as 'development that meets the needs of the present, without compromising the ability of future generations to meet their own needs' [4]. The focus of this research is on the environmental or 'green' aspects of sustainability. Due to increased scrutiny from customers, stakeholders, government legislations, environmental organizations and others, firms are pushed to consider the environmental impacts while doing their business [3], [5]. According to Beamon, business operations such as sourcing, manufacturing and logistics are the major causes of these environmental problems [6]. As a result, apart from organizational efforts to integrate green practices, a more externally oriented approach has emerged where firms try to extend environmental friendly practices throughout their supply chain [3]. According to Tachizawa, recent studies indicate a growing interest in Green Supply Chain Management (GSCM) with respect to 'greening' the multiple tiers of the supply chain [7]. Two main approaches of 'greening' are monitoring and collaboration between the various players involved in the supply chain. A large number of publications on the effects of environmental practices on the performance of the firm is present [8]-[12].

This literature review aims to systematically address the following research questions leading to a conceptual model designed to provide a vantage point of green supply chain management and its influence on performance. 
1. What are the drivers for 'greening' the supply chain?

2. What are the 'green supply chain methods' that can optimize the firm 's performance?

3. What are the impacts of these methods on the firms' performance?

This paper is structured as follows: section 2 presents the theoretical framework which describes the important theories used in this review, section 3 describes the research methodology used, section 4 presents the findings of the review, section 5 presents the discussion and section 6 concludes with a conceptual model, with the review being concluded in section 6 .

\section{Theoretical framework}

The following theories forms the groundwork for the literature review.

\subsection{Green Supply Chain Management (GSCM)}

Green Supply Chain Management has its roots in both environment management and supply chain management literature. Adding the 'green' component to supply chain management involves addressing the influence of and relationships between supply chain management and the natural environment [13]. Integrating environmental thinking into supply chain management includes considering product design, green purchasing, green manufacturing, materials management, green distribution/marketing and the delivery of the final product to the customer as well as reverse logistics $[13,14]$.

\subsection{Implementation of GSCM}

There are different reasons for implementing GSCM practices, it can be divided into proactive and reactive drivers [15]. A proactive strategy aims at anticipating competitors through systemic initiatives that affect the entire value chain e.g. eco-design practices, reverse logistics practices etc. [16], [17]. Meanwhile, a reactive strategy is intended to comply with environmental regulation and the environmental requirements from customers [15], [16].

\subsection{Sustainability metrics}

There are several metrics that help determine whether company activities are sustainable or not. According to Vance, the importance of using various metrics to assess sustainability is unquestionable. Sustainability metrics may involve material and energy management to community and governance, such as energy use or air emissions [18]. Companies can have different points regarding a specific metric or have applied their own individual metrics [19].

\section{Research methodology}

The process of this study involves a literature review to convey knowledge and attain credibility on the topic through already established literature [20], exploring different aspects of sustainable supply chain management. The objective of this methodology was to identify critical factors within sustainable supply chain with a focus on environmental pillars and how to optimize performance. 19 peer-reviewed journals were searched within a timespan of three years (2013-2016). Each journal article was skimmed with the keywords focusing on supply chain and sustainability/sustainable and/or environment/ecological. A total of 284 articles were found from the initial search and 125 articles were selected by comparing the title with the objective of the study. From these 125 articles, 10 articles were selected by comparing the focus, contribution and journal, with the objective of the study. A literature review was done on the 10 articles to address the research questions and a conceptual model was created to promote better understanding of the review. The contribution of articles from the different journals are: International Journal of Production Research (2), Journal of Cleaner Production (3), International Journal of Operations and Production Management (1), International Management and Data Systems (2), International Journal of Production Economics (1) and Supply Chain Management: An International Journal (1). 9 out of 10 articles use multiple methods. Only one paper is purely theoretical. Among the multiple research methods used there are five articles which also employ a case study, three articles test hypotheses from their theory, one use a survey and three mathematical modelling techniques. 


\section{Findings}

The focus of this review is on the environmental aspects of sustainable supply chain management, its consequential impacts and optimization of performance. The overview of the 10 relevant research papers is given in table 1.

Table 1: Overview of articles in the literature survey.

\begin{tabular}{|c|c|c|c|c|}
\hline Author & Year & Methodology & $\begin{array}{c}\text { Concepts } \\
\end{array}$ & Approach \\
\hline Dues, Tan and Lim & 2013 & $\begin{array}{l}\text { Literature review with } \\
\text { case study }\end{array}$ & $\begin{array}{l}\mathrm{CO}_{2} \text { emissions, waste } \\
\text { reduction, green practices }\end{array}$ & $\begin{array}{l}\text { Overlapping lean and green } \\
\text { paradigms. }\end{array}$ \\
\hline $\begin{array}{l}\text { Laosirihongthong, } \\
\text { Adebanjo and Tan }\end{array}$ & 2013 & $\begin{array}{l}\text { Literature review with } \\
\text { hypothesis testing }\end{array}$ & $\begin{array}{c}\text { Proactive and reactive } \\
\text { practices, business strategy }\end{array}$ & $\begin{array}{c}\text { Factor analysis, multivariate } \\
\text { linear regression }\end{array}$ \\
\hline Ahi and Searcy & 2014 & Literature review & $\begin{array}{l}\text { Composite environmental } \\
\text { metric system }\end{array}$ & $\begin{array}{c}\text { Conceptual framework to } \\
\text { measure environmental } \\
\text { performance }\end{array}$ \\
\hline $\begin{array}{c}\text { Ortas, Moneva and } \\
\text { Alvares }\end{array}$ & 2014 & $\begin{array}{l}\text { Research paper with } \\
\text { hypotheses testing, } \\
\text { empirical analysis }\end{array}$ & $\begin{array}{c}\text { Corporate Social } \\
\text { Responsibility, interaction } \\
\text { between Sustainable Supply } \\
\text { Chain Performance (SSCP) } \\
\text { and firm's Financial } \\
\text { Performance(FP) }\end{array}$ & Econometric models \\
\hline Mitra and Datta & 2014 & $\begin{array}{c}\text { Literature review, } \\
\text { survey and hypotheses } \\
\text { testing }\end{array}$ & $\begin{array}{l}\text { Supplier collaboration for } \\
\text { environmental sustainability, } \\
\text { economic performance }\end{array}$ & $\begin{array}{c}\text { Managerial implications for } \\
\text { the government and } \\
\text { companies }\end{array}$ \\
\hline Fahimnia et al. & 2015 & $\begin{array}{l}\text { Case study with } \\
\text { empirical analysis }\end{array}$ & $\begin{array}{l}\text { Fuel consumption, vehicle } \\
\text { travelling speed, rate of } \\
\text { carbon emissions }\end{array}$ & $\begin{array}{l}\text { Carbon pricing, fuel pricing, } \\
\text { mathematical model }\end{array}$ \\
\hline Jiang and Chen & 2015 & $\begin{array}{l}\text { Research paper with } \\
\text { numerical study }\end{array}$ & $\begin{array}{l}\text { Carbon emission sensitive } \\
\text { random demand, customer } \\
\text { behaviour }\end{array}$ & $\begin{array}{l}\text { Price sensitive demand } \\
\text { model, carbon emission } \\
\text { sensitive demand model }\end{array}$ \\
\hline $\begin{array}{l}\text { Tognetti, Grosse- } \\
\text { Ruyken and Wagner }\end{array}$ & 2015 & $\begin{array}{c}\text { Literature review and } \\
\text { case study }\end{array}$ & $\mathrm{CO} 2$ emissions, Energy mix & $\begin{array}{l}\text { Mathematical model for } \\
\text { network optimisation }\end{array}$ \\
\hline Vance et al. & 2015 & $\begin{array}{c}\text { Software model, case } \\
\text { study and numerical } \\
\text { analysis }\end{array}$ & $\begin{array}{c}\text { Ecological footprint, emergy } \\
\text { input }\end{array}$ & $\begin{array}{l}\text { P- graph framework, } \\
\text { modelling software }\end{array}$ \\
\hline Tachizawa et al. & 2015 & $\begin{array}{l}\text { Literature Review, } \\
\text { Case study with } \\
\text { empirical analysis }\end{array}$ & $\begin{array}{l}\text { GSCM drivers, approaches } \\
\text { and performance }\end{array}$ & $\begin{array}{c}\text { Collaborative GSCM } \\
\text { practices }\end{array}$ \\
\hline
\end{tabular}

\subsection{Drivers for adopting Green Supply Chain Management}

The implementation of GSCM can be divided into proactive and reactive drivers [15].

\subsubsection{Reactive drivers}

Within the context of GSCM, actors in the supply chain operate in a way that fulfils both customer and legal requirements. Companies have institutionalized environmental practices because of pressure from external and internal forces as well as an awareness of the consequences of non-compliance with environmental imperatives. Hence, pressures from government agencies and national/international regulators will influence the adoption of environmentally responsible behaviour [7], [15]. If companies have a legitimate concern for the environment and there is social approval, then environmental practices will be deployed more rapidly throughout the supply chain. It is important to note that the growth in adoption is in part because of institutional pressures driven by market and regulatory demands [7], [15], [21], [22], [23]. Examples of legislation are carbon pricing policies, carbon taxes and fuel prices [22]. 


\subsubsection{Proactive drivers}

Another driver is the 'slack resource theory' that argues, better financial performance can make slack financial and other resources available to invest in environmental performance, making companies' financial performance a predictor of environmental performance. The most successful companies have the most financial resources and can spend the most on environmental performance activities. The 'Good management theory' proposes a high correlation between good management practices and environmental performance because attention to environmental performance improves relationships with key stakeholders thereby improving firms' financial performance [24].

\subsection{Collaboration in Green Supply Chain Management}

While adopting GSCM practices, collaboration is crucial since a firm cannot be more environmentally sustainable than its suppliers [21]. The managers need to encourage all the parties involved in the chain to use sustainable practices and provide environment-friendly materials. According to Mitra and Datta [22], supplier collaboration, product design and logistics for environmental sustainability are the most significant Key Success Factors (KSF) impacting a firm's performance. One of the hypothesis proposed by Mitra \& Datta [21] suggests that collaborative relationships with suppliers are positively related to environmentally sustainable product design and logistics. Their results showed that supplier collaboration for environmental sustainability impacts the logistics and design of a product in a positive way, which in turn is positively related to competitiveness and economic performance of the firm. Based on arguments Tachizawa [7] hypothesize that collaborative GSCM practices are positively associated with environmental practices. Collaborative practices are essential to improve performance while monitoring only has indirect relationship through collaboration.

\subsection{Monitoring performance variables with metrics}

Metrics are often created to specifically focus on a particular goal and not to simultaneously address multiple issues in the supply chain. Hence composite metrics or a metrics system, capable of addressing the various sustainable supply chain characteristics is suggested [25]. Vance presents a computer-aided methodology for designing sustainable supply chains using the P-graph framework to develop supply chain structures which are then analysed using cost, the cost of producing electricity, and two sustainability metrics: the ecological footprint and the emergy input (which is the measure of energy used in transformations directly and indirectly to make a product or maintain a service) [18]. These metrics respectively represent environmental burden in terms of land use and energy resources. Tognetti, Grosse- Ruyken and Wagner give linear economic optimization models which involve metrics like: in-bound logistics/out-bound logistics emissions, total emissions, total revenues, total transportation costs etc. subjected to 7 constraints with respect to production and 5 environmental constraints [12]. Ortas, Moneva and Alvares use 8 Sustainable Supply Chain Performance (SSCP) indicators and 21 Financial Performance (FP) indicators for Granger causality test on sample of 3900 companies globally [24]. Fahimnia uses a practical optimization model to determine the optimal values for amount of goods produced at each manufacturing plant, amount of goods transported between manufacturers and retailers, vehicle's travelling speeds, backordered amounts and carbon emission and fuel consumption within each route [22].

\subsection{Green Supply Chain Management practices}

A literature review done by Tachizawa shows that some of the most commonly used GSCM practices are: environmental audits, supplier training and education, joint waste reduction with suppliers, joint process design with suppliers such as recycling, transportation, joint product design with suppliers such as design for reduced consumption of material/energy, design for recycling etc. [7]. Laosirihongthong, Adebanjo and Tan underline GSCM practices as: green purchasing practices, eco-design practices, reverse logistics practices, legislation and regulatory practices [15]. According to Dues, companies minimize the harm to the environment due to emissions by selecting suppliers of the same geographical area, managing the routes while delivering small amounts in order to supply multiple customers in the same area on one delivery route, using more efficient transport modes such as heavy-duty trucks and sharing trucks with other product lines and companies in order to use their full potential [26]. Fahimnia focuses on two relevant measures: fuel consumption and rate of carbon emissions since the transport sector accounts for a major part of the environmental impact of the supply chain [22]. 


\subsection{Impact of 'greening the supply chain' on performance}

The relationship between sustainable supply chain performance (SSCP) and financial performance (FP) has become a popular research topic because of its implications for corporate strategy, policy and economic sustainability [24] According to Dues, lean companies which include green practices achieve better lean results. Green practices aim to reduce the environmental risks and impacts while improving the ecological efficiency, such as eliminating the resource waste and pollution. Green practices further help with saving costs through the efficient use of resources and the reduction of redundant and unnecessary materials [26]. According to Mitra and Datta, sustainable supply chain improves the long-term economic performance of the individual company and its supply chains [21]. Firms have obtained economic and environmental benefits by taking back products and packages for recovery. One common practice for companies is remanufacturing, which reduces the production costs up to 40-60\% [21]. According to Tognetti, Grosse- Ruyken and Wagner, the results from the case study on German Automotive industry show that environmental performance can be improved by $30 \%$ without increase in variable cost [12].

The study by Fahimnia showed how Australia was forced to introduce carbon pricing due to pressure on transitioning towards low-carbon economy. By studying nine implications for manufacturing plants they discovered that greener plants coped better with the increased carbon price and carbon emissions went down [22]. The relationship between sustainable supply chain performance (SSCP) and financial performance (FP) has become a popular research topic because of its implications for corporate strategy, policy and economic sustainability [24]. There are two perspectives towards SSCP, one says that the better the financial performers are, the better chances the company has, to invest in improving their SSCP. The other view says that companies that increase their SSCP will increase their FP too. Companies can benefit from SSCP practices by being more efficient, having higher product quality, competitive advantage, access to new markets, increased employee motivation and satisfaction, improved public relations and better organizational reputation. The literature review performed by Laosirihongthong, Adebanjo and Tan suggested conflicting results between GSCM practices and organizational performance [15]. Some studies showed positive relationships between environmental practices and organizational performance, other studies showed that there is no significant relationship between such practices and organizational performance.

\section{Discussion}

The literature reviewed in this paper describes the various drivers for greening the supply chain and they have been broadly classified under proactive and reactive drivers. Various green practices have been described in the reviewed literature which can be used to improve the environmental performance of the supply chain. Literature also suggests that collaboration between the various entities of the supply chain is of paramount importance to have a successful green supply chain. Metrics are used to monitor the green supply chain performance, such as emissions, ecological footprint, the emergy input etc. By monitoring the firm's performance, strategies and practices can be improved. Conflicting results have been observed in the reviewed literature, with both positive and negative impacts on the firm's performance. Both quantitative and qualitative data shows positive impacts of implementing GSCM. However, some negative aspects of implementing GSCM practices has also been mentioned in the literature such as increase in costs and decrease in organizational performance. Some studies also suggests that there is no significant relationship between such practices and organizational performance. Some findings indicate that there is a synergy between such practices and improvement in environmental performance. These findings are illustrated with the conceptual model to promote better understanding of the conception and growth of a green supply chain. It suggests that there is a high potential to attain positive impacts on firm's supply chain performance with effective implementation of a green supply chain.

The limitations of this research include limited time frame (2013-2016) of the selected articles and a short sample of 10 articles gathered from peer-reviewed journals with the possibility of including more relevant literature from other journals. This study provides a conceptual model that collaborates the various aspects involved in the conception and implementation of green supply chain. It gathers the various literature on the GSCM topics and co-relates its impact on firms supply chain performance which can be used by academic researchers. However, applicability of this model has not been shown, which can be done with a case study providing opportunities for future research. This review can be used by companies and managers to evaluate their options, provide incentives to allocate resources and use the appropriate techniques to implement green supply chain. The research also provides an overview of metrics and practices which can be applied to measure and improve performance. 


\section{Conceptual concluding model}

In the literature review the research questions have been systematically addressed. The various drivers for greening the supply chain were identified and classified under reactive and proactive. The main green supply chain methods have been identified as collaboration, green practices and monitoring performance with metrics. For describing the various impacts of greening the supply chain, the results of 10 papers have been presented. These findings are concluded in the form of a conceptual model, see figure 1.

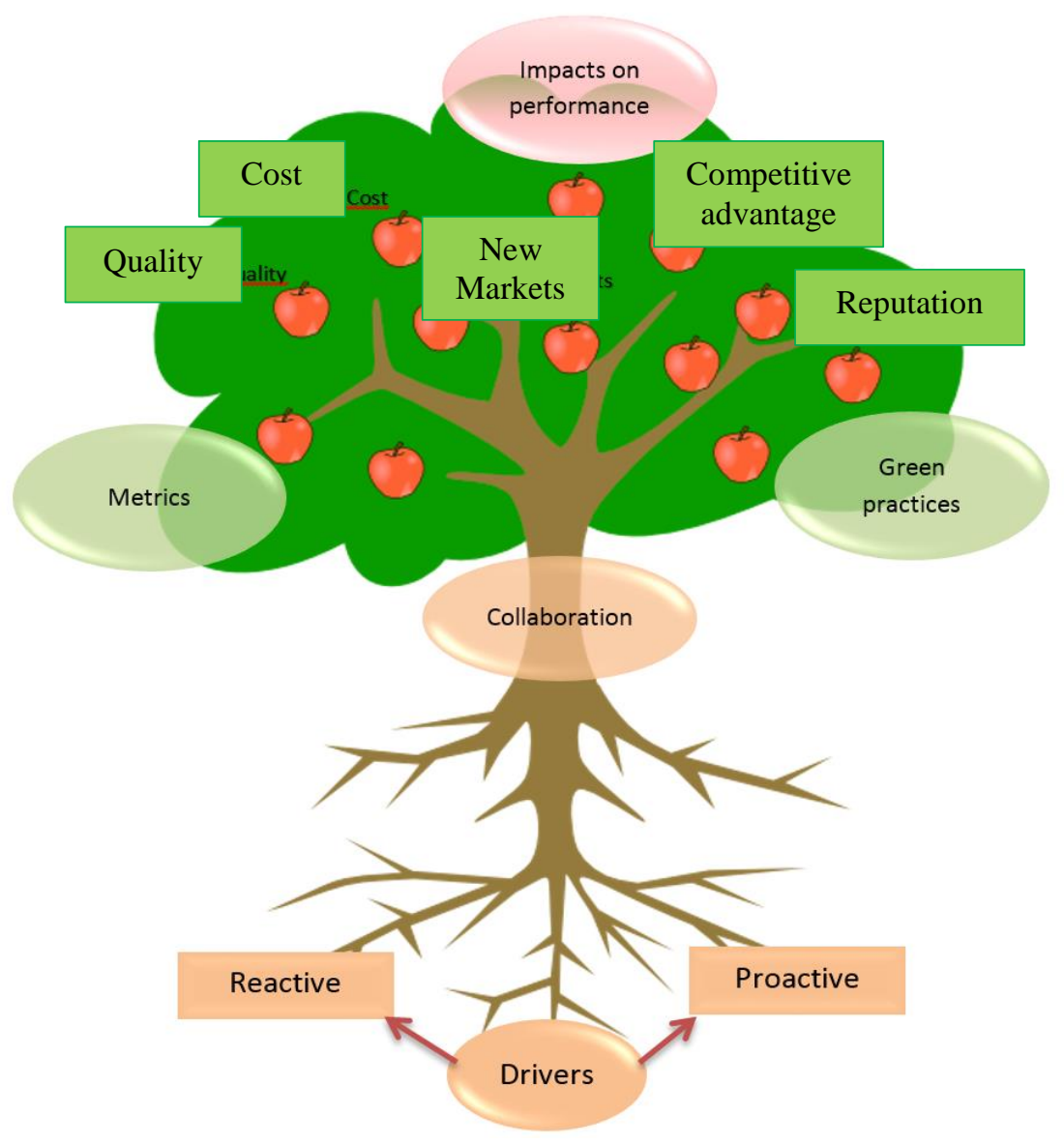

Fig. 1: The conceptual tree of Green Supply Chain Management.

\subsection{Growth of the conceptual model}

The drivers of greening a supply chain have been broadly classified under reactive and proactive drivers which has been compared to the functions served by the roots of the conceptual model as it drives its growth. Collaboration has been related to the trunk as it connects the various entities involved in the supply chain and it is crucial since a firm cannot be more environmentally sustainable than its suppliers [21]. Metrics and green practices symbolizes the leaves as they nurture and implement the functions of the green supply chain. Impacts of greening the supply chain has been interpreted as fruits of this conceptual model as it highlights the tangible effects of the process. This conceptual model has been illustrated by a tree due to its similar characteristics, right from its conception to its completely mature state. Initially proactive (i.e. gaining competitive advantage, new markets) and reactive drivers (i.e. legislations, customer demands) drive the birth and growth of the green supply chain network. Collaboration between the various suppliers and focal firms is essential to hold the whole network together, while green practices and metrics are essential to 'green' the supply chain. The impacts of the green supply chain can be observed once it reaches its mature state in the form of improvements in firm performance (i.e. cost, competitive advantages, quality, new markets etc.) similar to the fruits of a tree. 


\section{Acknowledgements}

We would like to take the opportunity to express our sincere gratitude to everyone who has supported and encouraged this research project. Initially, we would like to thank Johan Karltun for encouraging and supervising us during the review process of this research. We would also like to extend our gratitude to Patrik Cannmo and Jönköping University for supporting us financially. Finally, we sincerely thank David Eriksson for his assistance.

This would not have been possible without the warm support of our families and friends.

\section{References}

[1] M. Koho, M. Tapaninaho, J. Heilala, and S. Torvinen, "Towards a concept for realizing sustainability in the manufacturing industry," Journal of Industrial and Production Engineering, vol. 32, no. 1, pp. 12-22, 2015.

[2] WWF, Living Planet Report 2012, "Global footprint network: Earth overshoot day," 2012, [Online] Available: http://www.footprintnetwork.org/en/index.php/GFN/page/earth_overshoot_day/

[3] M. Garetti and M. Taisch, "Sustainable manufacturing: trends and research challenges," Production Planning \& Control, vol. 23.no. 2-3, pp. 83-104, 2012.

[4] World Commission on Environment and Development, Brundtland Commission, our common future, report of the World Commission on Environment and Development, 1987.

[5] J. Sarkis, (ed.), Greening the Supply Chain. Springer, London, 2006.

[6] B. M. Beamon, "Supply chain design and analysis: models and methods," International Journal of Production Economics, vol. 55, no. 3, pp. 281-294, 1998.

[7] E. M. Tachizawa, C. Gimenez and V. Sierra, "Green supply chain management approaches: drivers and performance implications," International Journal of Operations \& Production Management, vol. 35, no.11, pp. 1546- 1566, 2015.

[8] R. D. Klassen and C.P. McLaughlin, "The impact of environmental management on firm performance," Management Science, vol. 42, no. 8, pp. 1199-1214, 1996.

[9] A. McWilliams and D. Siegel, "Corporate social responsibility and financial performance: correlation or misspecification," Strategic Management Journal, vol. 21, no. 5, pp. 603-609, 2000.

[10] A. Gil, M. J. Jimenez and J. C. Lorente, "An analysis of environmental management, organizational context and performance of Spanish hotels," Omega, vol. 29, no. 6, pp. 457-471, 2001.

[11] B. W. Jacobs, V. R. Singhal and R. Subramanian, "An empirical investigation of environmental performance and the market value of the firm," Journal of Operations Management, vol. 28, no. 5, pp. 430-41, 2010.

[12] A. Tognetti, P. T. Grosse-Ruyken and S. M. Wagner, "Green supply chain network optimization and the trade-off between environmental and economic objectives," International Journal of Production Economics, vol. 170, pp. 385-392, 2015.

[13] K. Srivastava, "Green supply-chain management: A state of the-art literature review," International Journal of Management Review, vol. 9, no.1, pp. 53-80, 2007.

[14] A. Hervani and M. Helms, "Performance measurement for green supply chain management," Benchmarking: An International Journal, vol. 12, no. 4, pp. 330-353, 2005.

[15] T. Laosirihongthong, D. Adebanjo and K. Tan, "Green supply chain management practices and performance," Industrial Management \& Data Systems, vol. 113, no. 8, pp. 1088- 1109, 2013.

[16] G. Johansson and M. Winroth, "Introducing environmental concern in manufacturing strategies Implications for the decision criteria," Management Research Review, vol. 33, no. 9, pp. 877-899, 2010.

[17] G. Azzone and G. Noci, "Identifying effective PMSs for the deployment of 'green' manufacturing strategies," International Journal of Operations \& Production Management, vol. 18, no. 4, pp 308-335, 1998.

[18] L. Vance, I. Heckl, B. Bertok, H. Cabezas and F. Friedler, "Designing sustainable energy supply chains by the Pgraph method for minimal cost, environmental burden, energy resources input," Journal of Cleaner Production vol. 94, pp. 144-154, 2015.

[19] J. N. Rauch and J. Newman, "Research and solutions: zeroing in on sustainability," Sustainability: The Journal of Record, vol. 1, no.6, pp. 387-390, 2008.

[20] K. Williamson, "Two major traditions of research," In Research methods for students, academics and professionals: information management and systems, Wagga Wagga, 2002. 
[21] S. Mitra and P. Datta, "Adoption of green supply chain management practices and their impact on performance: an exploratory study of Indian manufacturing firms," International Journal of Production Research, vol. 52, no. 7, pp. 2085-2107, 2014.

[22] B. Fahimnia, J. Sarkis, J. Boland, M. Reisi and M. Goh, "Policy insights from a green supply chain optimisation model," International Journal of Production Research, vol. 53, no. 21, pp. 6522- 6533, 2015.

[23] W. Jiang, and X. Chen, "Optimal strategies for manufacturer with strategic customer behaviour under carbon emissions-sensitive random demand," Industrial Management \& Data Systems, vol. 116, no.4, 759-776, 2016.

[24] E. Ortas, J. M. Moneva and I. Álvarez, "Sustainable supply chain and company performance," Supply Chain Management: An International Journal, vol. 19 no. 3, pp. 332- 350, 2014.

[25] P. Ahi and C. Searcy, "An analysis of metrics used to measure performance in green and sustainable supply chains," Journal of Cleaner Production, vol. 86, pp. 360-377, 2015.

[26] C. Dües, K. Tan and M. Lim, "Green as the new Lean: how to use Lean practices as a catalyst to greening your supply chain,” Journal of Cleaner Production, vol. 40, pp. 93-100, 2013. 